\title{
Earnings Volatility, the Use of Financial Derivatives and Earnings Management: Evidence from an Emerging Market
}

\author{
Lian Kee Phua ${ }^{a}$ \\ Char-Lee Lok ${ }^{b}$ \\ Yong Xia Chuac \\ Tan-Chin Lim ${ }^{\mathrm{d}}$ \\ Universiti Sains Malaysia
}

\begin{abstract}
In the face of crises such as Covid-19, businesses become devastated by greater risk exposure, particularly in currency exchange, supply chain disruption, and fluctuation in commodity prices that cause volatile earnings trends. Higher earnings volatility is frequently associated with greater risk. Consequently, firms could be inspired to engage in earnings management or derivative use as attempts to mitigate earnings volatility. Using a sample of 169 of the largest non-financial firms with 507 firm-years observations from an emerging market, the researchers examined the relationship among derivative use, earnings volatility, and earnings management. The results of a panel regression analysis showed that derivative use by Malaysian public listed companies was positively connected with earnings volatility, inferring that the use of derivatives did not mitigate earnings volatility as intended. This study also found that both earnings volatility and derivative use have a positive relationship with earnings management. This implies that firms engage in earnings management to curb earnings volatility under circumstances where derivative use is associated with higher earnings volatility. Evidence derived from this study contributes to extant literature on financial risk management involving financial instruments, an area that is very much understudied in the contexts of emerging markets.
\end{abstract}

Keywords: Derivative use, discretionary accruals, earnings management, earnings volatility, risk management

JEL classification: G32, M41

a School of Management, Universiti Sains Malaysia, 11800, Penang, Malaysia. Email: phualk@usm.my

b School of Management, Universiti Sains Malaysia, 11800, Penang, Malaysia. Email: lokcl@usm.my (Corresponding author)

c School of Management, Universiti Sains Malaysia, 11800, Penang, Malaysia. Email: chuayongxia@yahoo. com or cyx15_man067@student.usm.my

d School of Management, Universiti Sains Malaysia, 11800, Penang, Malaysia. Email: tclim@usm.my

\section{Acknowledgements}

This research is supported by the Ministry of Education Malaysia (KPM), Fundamental Research Grant Scheme (FRGS) Phase 1/2016, under Grant No. 203 PMGT 6711543 of Universiti Sains Malaysia.

Article Info: Received 16 September 2020; Revised 22 December 2020; Accepted 22 February 2021 https://doi.org/10.22452/MJES.vol58no1.1 


\section{Introduction}

As one of the most prominent outputs of the accounting system, earnings figures are rich in information content. Earnings information is normally benchmarked against specific measures to provide valuable insights into various financial issues for economic decision-making. For instance, in horizontal or time-series analyses, comparisons of earnings figures can be conducted using quarterly or annual earnings data to analyse earnings quality. In such analyses, an important indicator of earnings quality is measured by its volatility. Earnings volatility refers to how earnings of a business fluctuate over time. Rational risk averse investors would prefer less volatile earnings trends. Stable earnings trends can be useful input for the prediction of future earnings performance (Hairston \& Brooks, 2019). In fact, Gordon's dividend growth model uses the assumption of stable and predictable increase in dividend payout to forecast a company's share price (Verdickt et al., 2019).

Under the ambit of profit-oriented corporations, managers are employed to maximise shareholder wealth. However, conflicts of interest between managers and shareholders result in agency problems whereby managers may not act in the best interest of the owners. To align the interest between managers and shareholders, managerial compensation is commonly built around earnings targets by which meeting these targets can lead to lucrative bonuses. Consequently, under such reward systems, managers are inclined to report smooth earnings that show upward trends with low volatility. As a result, managers are prone to engage in earnings management so that the reported earnings will favour their self-interest. As accrual basis is used for preparation of financial statements, managers can thus use their discretion in decisions pertaining to changes in accounting policies and accounting estimates in their attempts to manage earnings. Prior studies proved that earnings management has been used as a primary approach or a substitute approach to reduce earnings volatility (Kousenidis et al., 2003; Pincus \& Rajgopal, 2002).

For the case of Malaysia, research on earnings management tends to concentrate on corporate governance issues such as audit quality, audit committee (Mohd Saleh et al., 2007), influence of women directors, family control (Abdullah \& Ismail, 2016), and board ethnicity (Wan Mohammad et al., 2016). Lau (2016) found that firms in Malaysia that use derivatives perform better in terms of operating performance compared to non-users. Oktavia et al. (2019) revealed that financial derivatives reduce the impact of earnings management by using a sample of Association of Southeast Asian Nations (ASEAN) countries that comprised of the Philippines, Indonesia, Malaysia and Singapore.

Apart from internal factors, a number of external factors, including business risk, interest rates, commodity prices and exchange rates, can affect the earnings and value of a firm. For instance, the shift in interest rates and exchange rates can augment income and induce earnings and thus impact cash flows volatility. Managers may apply derivative instruments to alleviate various types of financial risk and to manage earnings volatility. A review conducted by Tahat et al. (2019) noted that the use of financial derivative instruments has seen exponential increase globally over the last two decades with a surge in the total notional amount of derivatives by $1,700 \%$ from $\$ 57.5$ trillion to \$696 trillion between 1990 and 2012 (Abdel-khalik \& Chen, 2015) and an 
increase over $700 \%$ between 1998 to 2018 from $\$ 72$ trillion to $\$ 600$ trillion (Campbell et al., 2019). Firms can use derivatives as risk management tools to hedge the impact of adverse price or market movements on fair values or cash flows. Alternatively, firms may speculate in derivatives that are not offset by any asset or liability and thus increase their risk exposure (Campbell et al., 2019; Hairston \& Brooks, 2019).

Previous studies highlighted that the use of derivatives affects earnings volatility (Alkebäck et al., 2006; Assa, 2016; Barnes, 2002; Barton, 2001; Pincus \& Rajgopal, 2002). Brown (2000) concluded that firms that use foreign currency derivatives to hedge exchange risk reported smoother earnings and their share prices are traded at higher values compared to those not using derivatives. In some circumstances, instead of eliminating the risks in earnings and cash outflow fluctuations, the use of financial derivatives brings more harm by causing a firms' earnings and cash outflow to become more volatile, due to the failure of derivative instruments function to hedge effectively. All the gains or losses that arise from the fair value adjustments on the values of derivatives are accounted for in the current period's net profit and consequently cause greater earnings volatility. Singh (2004) found that there is a positive relationship between derivative use and earnings smoothing.

In summary, (i) earnings volatility is frequently associated with higher risk, thus firms tend to maintain a less volatile earnings pattern over time, (ii) firms could be motivated to engage in earnings management as an attempt to mitigate earnings volatility, and (iii) financial derivatives have been employed as a tool to curb earnings volatility and their usage has increased tremendously over the past two decades. These observations give rise to a few interesting issues. In emerging markets, the use of financial derivatives is particularly constrained by a lack of expertise and good knowledge pertaining to these complicated financial instruments (Deloitte, 2009). Nonetheless, with increased globalised economic activities in the present era, it has become inevitable for firms to start using derivative instruments to hedge various business risks. However, the use of derivatives would not assure that a firm can successfully mitigate risks. If the derivative users hedge inefficiently, it can adversely affect the firm's earnings and cash flows. It is therefore of interest to examine the relationship between earnings volatility and earnings management, as well as earnings volatility and derivative use in the context of an emerging market, to shed light on the understanding of the use of derivatives as a financial risk management tool in developing markets.

Being one of the developing countries in Southeast Asia, Malaysia is one of the Asian countries that has gained stable and consistent growth in gross domestic product for the past decade. Malaysia's economy depends heavily on export of commodities, namely palm oil, crude oil, rubber and electronic products. Its trading partners are China, Singapore, United States, Hong Kong and other neighbouring countries. Businesses are exposed to currency risks and fluctuations of commodity prices. The Malaysian Ringgit plummeted significantly in 2015 and suffered a large decline against major world currencies (Quadry et al., 2017) following the collapse of the global oil price (Manning, 2015). The significant plunge in value of the Malaysian currency has led companies in Malaysia to face severe currency risks. A startling case is that of IOI Corporation, a public listed company that recognised a net foreign currency translation 
loss in foreign currency denominated borrowings and associated finance costs of RM1 billion in 2015, which eventually wiped off its reported profits by $70 \%$ (IOI Corporation Berhad, 2015).

Financial crises associated with the depreciation of the Ringgit and the fluctuation of commodities prices ignited interest to study measures taken by Malaysian listed companies to alleviate earnings volatility. In other words, researchers examined how public companies attempted to mitigate their earnings volatility that arose from financial risks. There was inadequate empirical evidence that relates to the use of financial derivatives and their effect on earnings volatility of Malaysian listed companies. It is crucial to conduct more research on a developing economy like Malaysia, as the findings of the research in developed countries may not be applicable to emerging markets due to differences in the contextual environment, such as familiarity and competency in deploying derivatives instruments, capital market efficiency, rules and regulations.

\section{Literature Review and Hypotheses Development}

\subsection{Use of Financial Derivatives and Earnings Volatility}

The legendary investor, Warren Buffet states that derivatives are "financial weapons of mass destruction" if not utilised properly (Cox, 2018). On a dangerous side, the use of derivatives may increase earnings volatility as a firm faces higher risk, or on a good side, derivative use may mitigate earnings volatility when it functions as an effective risk management tool. Warren Buffet perceived that derivatives are used for the purpose of capitalising on discrepancies in the market (Oppel \& Sorkin, 2001). Evidence from empirical findings of prior studies revealed that the use of financial derivatives has a direct impact on earnings volatility (El-Masry, 2006; Geczy et al., 1997; Jalilvand et al., 2000; Shen \& Hartarska, 2013). In contrast, Barton (2001) found that derivative users were having less volatile cash flows and lower total accruals as compared to nonusers. The results suggested a negative relationship between the use of derivatives and earnings volatility. Hu and Zhou (2006) examined whether the introduction of Statement of Financial Accounting Standards (SFAS) No.133 affected earnings volatility. They found that earnings volatility might affect managers' hedging decisions. As noted by Oppel and Sorkin (2001), Buffet claimed that those companies who use derivatives might have other motives instead of hedging. Buffet perceived that most companies involved in the use of derivatives aim to smooth their earnings, trying to make quarterly numbers less volatile (Oppel \& Sorkin, 2001). The theoretical arguments focusing on corporate risk management theory suggest that the use of derivatives aims to reduce earnings volatility by addressing issues of financial distress costs, costly external financing, asymmetry in tax costs, and costs of managerial risk aversion (Smith \& Stulz, 1985; Jacque, 2010 as cited in Tahat et al., 2019).

From the above discussion, two important extreme observations are derived, argument grounding from corporate risk management theories suggest that the use of derivatives aims to reduce earnings volatility. However, if the use of derivatives is ineffective, it will trigger higher earnings volatility. Derivatives can also be used for 
speculative purposes in which it may increase risk exposure of firms. Given that no supporting evidence on which view hold in the context of an emerging market, the researchers hypothesised that:

$\mathrm{H}_{1}$ : There is a significant association between derivative use and earnings volatility.

\subsection{Earnings Management and Earnings Volatility}

Prior research documented that managers have the incentives to manage the earnings of an organisation with the purpose to reduce volatility and ease the forecasted future earnings of the organisation. Therefore, media, practitioners and regulators have shown increasing concern regarding these overwhelming applications of earnings management practices by managers to smooth firms' earnings. Goel and Thakor (2003) developed a model in which the earnings smoothing technique is intensified by the desire to reduce the perceived volatility of a firms' earnings stream and discourage speculators from spending resources to acquire private information that could then be used to trade against shareholders selling for liquidity reasons. Greater earnings volatility leads to a bigger informational advantage for informed investors over uninformed investors. Asymmetry of information disfavours current uninformed shareholders who need to execute trade in the future for liquidity reasons with an increase in the volatility of reported earnings magnifying these shareholders' trading losses. Hence, managers would be motivated to engage in earnings management in an attempt to reduce earnings volatility. Thus, researchers have formulated the following hypothesis:

$\mathrm{H}_{2}$ : There is a positive relationship between earnings volatility and earnings management.

\subsection{Use of Financial Derivatives and Earnings Management}

Barton (2001) and Pincus and Rajgopal (2002) have completed substantive studies on the relationships between the use of derivatives, earnings volatility and earnings management. They recommended that the option to use derivatives and discretionary accruals for earnings management could either result from a joint decision or a sequential decision. Both of the studies presented different views in regard to how these three variables are related to each other. While Barton (2001) concluded that derivative use and earnings management could be substituted in managing earnings volatility, on the other side, Pincus and Rajgopal (2002) suggested that derivative use gives rise to earnings volatility, and consequently, earnings management was employed to reduce earnings volatility. At the same time, they critically argued that Barton's findings suffered from shortcomings in their methodology. Nonetheless, the findings of Pincus and Rajgopal (2002) might not be generalised to other industries, as their sample only involved the gas and oil industry. Hu and Zhou (2006) showed that the use of derivatives and accruals indicated a negative relationship between each other, which implied that derivatives and accruals could be used as partial substitutes by managers to smooth the earnings volatility of their companies. In conclusion, the empirical evidence from the extant literature has presented two contradictory views with regard 
to the relationships between derivative use and earnings management. In the contexts of emerging markets, as this area is very much understudied, the following hypothesis with no specific directional relationship was proposed:

$\mathrm{H}_{3}$ : There is a significant association between derivative use and earnings management.

\section{Data and Methodology}

\subsection{Sample Firms}

Firm-level data was used as the unit of analysis of this study. In line with the practice in finance quantitative studies, companies from finance, insurance and real estate investment trusts (REITs) were deliberately excluded from the sample due to different accounting practices and regulations. Five firms with abnormal accrual outliers (each with more than five standard deviations from the mean) were removed.

Several empirical studies have proven that larger firms are more likely to use derivatives as compared to smaller firms (Alkebäck et al., 2006; El-Masry, 2006; Glaum \& Klöcker, 2011; Hon, 2013). Based on evidence presented by Oktavia et al. (2019), derivative usage among Malaysian listed companies was not as popular as those in developed countries, with around 20-25\% derivative users between years 2009 and 2013. Therefore, this research selected the largest sample of non-financial companies from Bursa Malaysia. The measure of firm size was based on total assets because it is the most widely used measurement in accounting research.

Table 1 depicts the filtration procedure to obtain the final sample of firms in this study. Data on the use of derivatives and quarterly earnings were manually collected from companies' annual reports, which were downloaded from the Bursa Malaysia website. The data to compute earnings management (discretionary accrual), earnings volatility and other financial data were extracted from Thomson Reuters Datastream database. For the measurement of earnings management, this study extracted the data of all the listed companies in Bursa Malaysia to calculate the coefficient of the discretionary accrual for each industry.

The period of this study was from 2015 to 2017, during which the Malaysian Ringgit currency exchange rate (RM/USD) fluctuated tremendously. According to Figure 1 , there was a sharp depreciation of Ringgit Malaysia against USD in 2015, and the average exchange rate increased from RM3.27/USD (2014) to RM3.91/USD (2015) with

Table 1. Filtration procedure of the sample firms

\begin{tabular}{lc}
\hline Data filtration procedure & Number of firms \\
\hline Top 200 companies excluding finance and insurance companies & 200 \\
- REITs sector & 11 \\
- Missing data from database (Datastream) & 15 \\
- Outliers & 5 \\
\hline Final sample firms & 169 \\
\hline
\end{tabular}




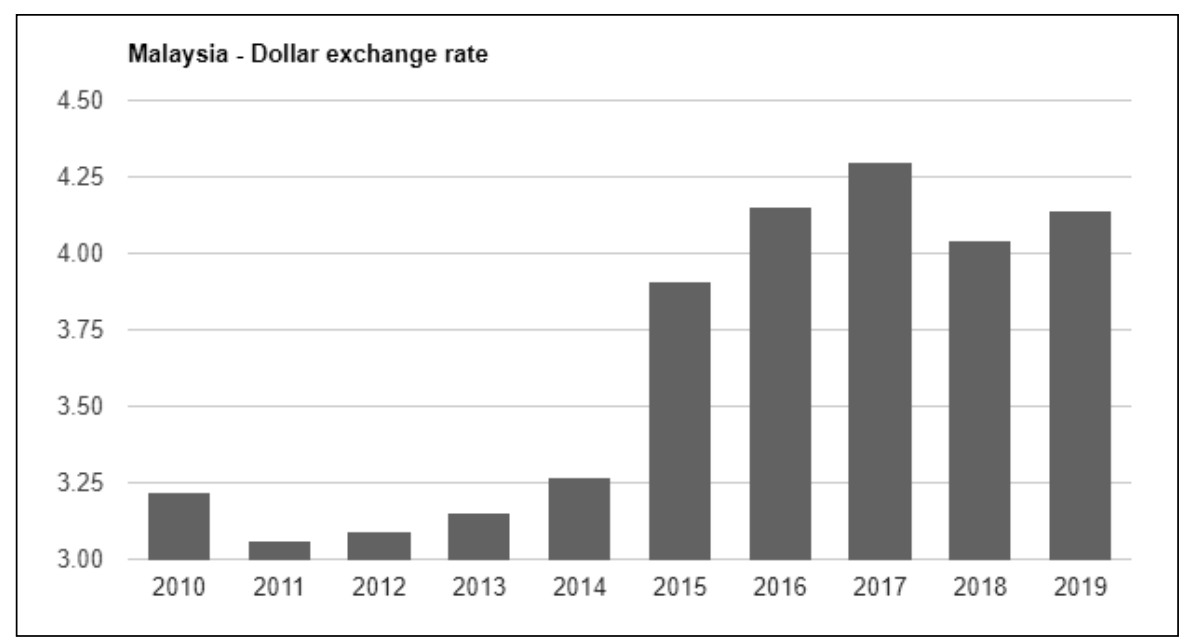

Figure 1. Currency exchange rate (RM/USD) Source of data: TheGlobalEconomy.com

a severe depreciation of $19.57 \%$. In 2016, the Ringgit depreciated further to RM4.15/ USD and subsequently to RM4.30/USD in 2017 with a percentage depreciation of $6.14 \%$ and $3.6 \%$ respectively. The contextual environment that reflected a higher risk of currency crisis during 2015 to 2017 provides a good avenue to examine the research issues proposed in this study, as the preliminary data collected by the authors showed that most Malaysian companies mainly engaged in derivative use to deal with foreign currency risk (Table 2).

Table 2. Types of derivative used by Top 200 companies* in year 2015

\begin{tabular}{lcccc}
\hline Types of derivatives & $\begin{array}{c}\text { Number } \\
\text { of users }\end{array}$ & $\begin{array}{c}\text { Percentage } \\
\text { (\%) }\end{array}$ & $\begin{array}{c}\text { Number } \\
\text { of non-users }\end{array}$ & $\begin{array}{c}\text { Percentage } \\
\text { (\%) }\end{array}$ \\
\hline Forward foreign exchange contract & 59 & 29.5 & 141 & 70.5 \\
Cross currency swap & 9 & 4.5 & 191 & 95.5 \\
Cross currency interest rate swap & 15 & 7.5 & 185 & 92.5 \\
Interest rate swap & 28 & 14 & 172 & 86.0 \\
Interest rate capped Libor-in-arrears & 3 & 1.5 & 197 & 98.5 \\
swap / Interest rate cap & 10 & 5.0 & 190 & 95.0 \\
Commodity futures contract & 6 & 3.0 & 194 & 97.0 \\
Commodity swap contract & 4 & 2.0 & 196 & 98.0 \\
Call spread options / Call option right & 11 & 5.5 & 189 & 94.5 \\
Others & & & & \\
\hline
\end{tabular}

Note: * Top 200 companies are measured by the value of total assets in 2015 .

Source of data: Annual reports of 2015 retrieved from https://www.bursamalaysia.com/ 


\subsection{Measurement of Variables}

(a) Earnings Management

A widely used accounting approach by empirical researchers to identify earnings management is modelling the accrual process (DeAngelo, 1986; Dechow \& Sloan, 1991; Dechow et al., 1995; Healy, 1985; Jones, 1991). Although the accrual basis accounting method provides true and fair view on the performance of a firm as compared to the cash basis accounting, it embodies higher managerial discretion in accounting choices. Typically, accruals arise due to timing differences between recognition of accounting transactions and cash flows whereby normal accruals represent adjustments that capture fundamental performance while abnormal accruals proxy for accounting distortions (Dechow et al., 2010). The milestone in the accruals approach is the study of Jones (1991) who defined the accrual process as a function of sales growth and investment in property, plant and equipment. It is argued that Jones' (1991) model suffers from low explanatory power for empirical studies. To address Type II error related to the proxy of earnings management in Jones' (1991) model, the Modified Jones model was introduced by Dechow et al. (1995) with adjustment for growth in credit sales. This study adopted the Modified Jones model (Dechow et al. 1995) as demonstrated in the following steps:

Step 1: To compute total accruals defined as the difference between net income and operating cash flows. The formula was as follows:

\section{Total accrual $=$ Net income - Cash flows from operating activities}

Step 2: To compute the industry coefficients by regressing the following model using the full data set available for each industry. Industry classification by Bursa Malaysia was adopted in this study.

$$
\text { Total Accrual/ } A_{i t-1}=\alpha_{1}\left(1 / A_{i t-1}\right)+\alpha_{2}\left(\Delta R E V_{i t}-\triangle R E C_{i t}\right) / A_{i t-1}+\alpha_{3}\left(P P E_{i t} / A_{i t-1}\right)+\varepsilon
$$

where:

$$
\begin{aligned}
& A_{i t-1} \quad=\text { Total asset in period } t-1 \\
& \triangle R E V_{i t} \quad=\text { Change in revenues for period } t \\
& \triangle R E C_{i t} \quad=\text { Change in net receivables for period } t \\
& P P E_{i t} \quad=\text { Property, plant and equipment for period } t \\
& \alpha_{1}, \alpha_{2}, \alpha_{3}=\text { Regression coefficients }
\end{aligned}
$$

Step 3: To compute the non-discretionary accruals (NDA) by substituting the respective industry coefficient derived from step 2 into the equation given below:

$$
N D A=\alpha_{1}\left(1 / A_{i t-1}\right)+\alpha_{2}\left(\Delta R E V_{i t}-\Delta R E C_{i t}\right) / A_{i t-1}+\alpha_{3}\left(P P E_{i t} / A_{i t-1}\right)+\varepsilon
$$

Step 4: To compute discretionary accrual (DA), defined as NDA subtracted from total accruals scaled by total assets (Total Accrual $/ A_{i t-1}$ ). The absolute value of discretionary accruals was used as a measure of the magnitude of earnings management.

Discretionary accrual $(D A)=$ Total Accrual $/ A_{i t-1}-N D A$ 
This study used abnormal accruals as a proxy to infer the engaged earnings management controlling for firm size in line with the practice of prior studies such as Cohen and Zarowin (2010), Dechow et al. (1995), Ghazali et al. (2015), Holthausen et al. (1995), Lin (2011) and Tort (2013).

\section{(b) Earnings Volatility}

Prior studies have attempted to measure earnings volatility as the standard deviation of earnings scaled by total assets (earnings before interest and tax divided by average total assets) over different time intervals. Barton (2001), Hu and Zhou (2006) and Singh (2004) conducted their tests using annual earnings over five years. A more recent work by Beneda (2013) computed earnings volatility as the standard deviation of eight quarterly earnings over a 2-year period, including the current sample and prior year of annualised operating returns. This study adopted the method used by Beneda (2013) to measure earnings volatility based on the standard deviation of deflated earnings (EBIT/ average total assets) for the most recent eight quarters. Prior studies suggested that a better indicator of earnings volatility is over two years, as the time span provides a better match to derivative use (Beneda, 2013; Dichev \& Tang, 2008).

\section{(c) Derivative Use}

Derivative use is widely measured by using a dichotomous variable (Alkebäck et al., 2006; El-Masry, 2006; Geczy et al., 1997; Jalilvand et al., 2000) or based on the total or aggregate notional values (Barton, 2001; Pincus \& Rajgopal, 2002; Singh, 2004). Researchers argued that one of the best measures of a firms' derivative use is the ratio of the derivative position to the amount of risk exposure the firm is trying to hedge (Barton, 2001). Unfortunately, most firms do not disclose adequate information for computation of the ratio. This research captured the use of financial derivatives of each firm by a dummy variable. By using a content analysis on annual reports, derivative users were identified as those companies that met any of the following criteria:

Criteria 1: Disclosure in the notes of the financial statement about the use of financial derivatives to mitigate their financial risks, such as foreign exchange risk, interest rate risk, commodity risk and others, according to the risk management disclosure as required by Malaysian Financial Reporting Standard 7.

Criteria 2: Disclosure of notional amounts of derivative instruments in the notes of financial statements.

Criteria 3: Disclosure of the amount of loss or gain on derivatives or the amount of derivative asset/liability in the financial statements.

\section{(d) Control Variables}

Four control variables were used in this research, namely, auditor firm size (Jordan et al., 2010), growth opportunity (Huang et al., 2015), firm size (Barton 2001) and leverage (Barton, 2001; Ghazali et al., 2015), based on a review of extant literature. 


\subsection{Model Specification}

The following equations were developed to test the research hypotheses:

$$
\begin{aligned}
& E V_{i t}=\alpha+\beta_{1}\left(F D_{i t-1}\right)+\beta_{2}\left(\text { AudFS }_{i t}\right)+\beta_{3}\left(G r_{i t}\right)+\beta_{4}\left(F S_{i t}\right)+\beta_{5}\left(\operatorname{Lev}_{i t}\right)+\varepsilon_{i} \\
& E M_{i t}=\alpha+\beta_{1}\left(E V_{i t}\right)+\beta_{2}\left(\text { AudFS }_{i t}\right)+\beta_{3}\left(G r_{i t}\right)+\beta_{4}\left(F S_{i t}\right)+\beta_{5}\left(\operatorname{Lev}_{i t}\right)+\varepsilon_{i} \\
& E M_{i t}=\alpha+\beta_{1}\left(F D_{i t-1}\right)+\beta_{2}\left(\text { AudFS }_{i t}\right)+\beta_{3}\left(G r_{i t}\right)+\beta_{4}\left(F S_{i t}\right)+\beta_{5}\left(\operatorname{Lev}_{i t}\right)+\varepsilon_{i}
\end{aligned}
$$

where,

$$
\begin{aligned}
E M_{i t}= & \text { Discretionary accrual scaled by total assets, Total accrual } / A_{t-1}=\alpha_{1}\left(1 / A_{t-1}\right) \\
& +\alpha_{2}\left(\triangle R E V_{i t}-\triangle R E C_{i t}\right) / A_{i t-1}+\alpha_{3}\left(P P E_{i t} / A_{t-1}\right)+\varepsilon \\
E V_{i t}= & \text { Earnings volatility, measured as the standard deviation of earnings for } \\
& \text { the most recent } 8 \text { quarters divided by total assets (where } t=\text { year } 2015 \\
& \text { to 2017) } \\
F D_{i t-1}= & \text { Derivative use is a dummy variable, } 1 \text { denotes users of derivatives and } 0 \\
& \text { otherwise } \\
A u d F S_{i t}= & \text { Auditor firm size is a dummy variable, } 1 \text { denotes a big-four firm and } 0 \\
& \text { otherwise } \\
G r_{i t}= & \text { Growth opportunity is market value of the ordinary (common) equity } \\
& \text { divided by book value of the ordinary (common) equity } \\
F S_{i t}= & \text { Firm size is the natural logarithm of total assets } \\
L e v_{i t}= & \text { Leverage is the percentage of total liabilities divided by total assets } \\
\varepsilon \quad= & \text { Error term }
\end{aligned}
$$

\section{Results and Discussion}

\subsection{Descriptive Statistics}

Table 3 depicts the descriptive statistics of the variables. In panel A, 52.66\%, or 267 out of 507 firm-years, of the sample were derivative users. This indicates that among the $25 \%$ largest firms listed in Bursa Malaysia, only slightly more than half of them were derivative users. As noted in the literature, derivatives are more commonly used by large companies, but the sample for this study implied that derivatives are not widely adopted by Malaysian companies, probably due to its complex nature and difficulty to get expertise to use it efficiently. This is consistent with findings reported by Lau (2016) and Okatvia et al. (2019). Panel A also exhibits that 409 (80.67\%) firm-years appointed Big Four audit firms as their auditors, while only 98 (19.33\%) firm-years appointed non-Big Four. These results show that Big Four audit firms were the preferred auditors among large firms in Malaysia.

In Panel B, the average value of accrual earnings management is 0.0657 . As the objective of the study was to determine the relationships between earnings management and derivative use, the magnitude of earnings management was measured by its absolute value instead of negative or positive values, which implies income increasing or decreasing earnings management practices. The descriptive analysis showed that the magnitude of discretionary accrual scaled by total assets ranged from 0.0001 to 0.8409 . 
Table 3. Descriptive statistics

\begin{tabular}{|c|c|c|c|c|c|}
\hline Panel A: Usage of derivatives & & Frequency & \multicolumn{2}{|c|}{ Percentage } & \\
\hline Derivatives non-users & & 240 & \multicolumn{2}{|c|}{47.34} & \\
\hline Derivatives users & & 267 & \multicolumn{2}{|c|}{52.66} & \\
\hline Total & & 507 & \multicolumn{2}{|c|}{100} & \\
\hline Auditor firm size & & Frequency & \multicolumn{2}{|c|}{ Percentage } & \\
\hline Big Four & & 409 & \multicolumn{2}{|c|}{80.67} & \\
\hline Non-big Four & & 98 & \multicolumn{2}{|c|}{19.33} & \\
\hline Total & & 507 & \multicolumn{2}{|c|}{100} & \\
\hline Panel B: Variables & Observations & Mean & Std. Dev. & Min & Max \\
\hline Earnings management (EM) & $N=507$ & 0.0657 & 0.0826 & 0.0001 & 0.8409 \\
\hline Earnings volatility (EV) & $N=507$ & 1.3173 & 2.6134 & 0.0391 & 29.1041 \\
\hline Growth opportunity (Gr) & $N=507$ & 2.1014 & 6.8183 & -3.5400 & 92.3700 \\
\hline Firm size (RM million) & $N=507$ & 8,752 & 16,538 & 460 & 144,209 \\
\hline Leverage (\%) & $N=507$ & 28.3011 & 16.9616 & 0 & 87.7996 \\
\hline
\end{tabular}

The mean and standard deviation for earnings volatility were 1.3173 and 2.6134 respectively. This indicates that the earnings volatility of the sample firm-years was rather widely dispersed from the mean value. In addition, the minimum value of earnings volatility was only $3.9 \%$, while the maximum value of long-term earnings volatility went up to more than $100 \%$. There was a huge gap in the range of earnings volatility values. Similar patterns were observed for variables of growth opportunity and firm size. This justifies the need to control for firm size even though the sample firms were selected based on the top 200 largest listed firms. A natural logarithm of firm size was applied and used in the statistical analysis.

The analysis showed that the mean and standard deviations of leverage were $28.30 \%$ and $16.96 \%$ respectively. The minimum value of leverage was zero, while the maximum value of the leverage went up to $87.80 \%$. The mean indicated that the majority of the top 169 Malaysian listed companies were less likely to leverage their firms since their average leverage was less than one third (28.3\%). It also implied that the majority of Malaysian firms' resources were sourced by internal funding rather than funding by third parties.

\subsection{Baseline Results}

Table 4 depicts the results for panel data regression. Model 1 examined the relationship between the usage of derivatives and earnings volatility to address hypothesis 1 . The results showed that usage of derivatives affects earnings volatility marginally with a positive coefficient of 0.6542 . This suggests that usage of derivatives increases earnings volatility in firms. In the literature, there are two views with regard to the intent to use 
Table 4. Baseline regression results

\begin{tabular}{|c|c|c|c|c|}
\hline & Model 1 & Model 2 & Model 3 & Model 4 \\
\hline Dependent variable & EV & EM & EM & EM \\
\hline $\mathrm{FD}_{(t-1)}$ & $\begin{array}{c}\mathbf{0 . 6 5 4 2} * \\
(0.3502)\end{array}$ & & $\begin{array}{l}\mathbf{0 . 0 2 4 9 * *} \\
(0.0099)\end{array}$ & $\begin{array}{l}\mathbf{0 . 0 2 2 1}^{* *} \\
(0.0098)\end{array}$ \\
\hline EV & & 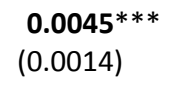 & & $\begin{array}{l}\mathbf{0 . 0 0 4 3 * * *} \\
(0.0015)\end{array}$ \\
\hline AudFS & $\begin{array}{c}0.2521 \\
(0.4089)\end{array}$ & $\begin{array}{l}\mathbf{0 . 0 2 9 1 * * *} \\
(0.0091)\end{array}$ & $\begin{array}{l}\mathbf{0 . 0 3 0 1 * * *} \\
(0.0115)\end{array}$ & $\begin{array}{l}\mathbf{0 . 0 2 9 0 * *} \\
(0.0114)\end{array}$ \\
\hline $\mathrm{Gr}$ & $\begin{array}{l}-0.0456^{*} \\
(0.0253)\end{array}$ & $\begin{array}{c}0.0000 \\
(0.0005)\end{array}$ & $\begin{array}{l}-0.0003 \\
(0.0007)\end{array}$ & $\begin{array}{l}-0.0001 \\
(0.0007)\end{array}$ \\
\hline FS & $\begin{array}{l}-0.6861 * \\
(0.3676)\end{array}$ & $\begin{array}{l}-0.0320^{* * *} \\
(0.0077)\end{array}$ & $\begin{array}{l}-0.0454^{* * *} \\
(0.0103)\end{array}$ & $\begin{array}{l}-0.0424^{* * *} \\
(0.0103)\end{array}$ \\
\hline Lev & $\begin{array}{c}0.0113 \\
(0.0096)\end{array}$ & $\begin{array}{c}0.0002 \\
(0.0002)\end{array}$ & $\begin{array}{c}0.0004 \\
(0.0003)\end{array}$ & $\begin{array}{c}0.0004 \\
(0.0003)\end{array}$ \\
\hline _cons & $\begin{array}{l}\text { 7.3056** } \\
(3.4275)\end{array}$ & $\begin{array}{l}0.3366^{* * *} \\
(0.0732)\end{array}$ & 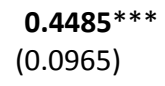 & $\begin{array}{l}\mathbf{0 . 4 1 7 0 * * *} \\
(0.0961)\end{array}$ \\
\hline $\mathrm{N}$ & 338 & 507 & 338 & 338 \\
\hline$r^{2}$ & 0.0254 & 0.0722 & 0.0722 & 0.0940 \\
\hline
\end{tabular}

Note: $* * *, * * *$ denotes significance level at $10 \%, 5 \%$ and $1 \%$ respectively.

$E M$ is the discretionary accrual scaled by total assets, Total Accrual/ $A_{t-1}=\alpha_{1}\left(1 / A_{t-1}\right)+\alpha_{2}\left(\Delta R E V_{i t}-\right.$ $\left.\triangle R E C_{i t}\right) / A_{t-1}+\alpha_{3}\left(P P E_{i t} / A_{t-1}\right)+\varepsilon$ (Modified Jones model); $E V$ is the earnings volatility, measured as the standard deviation of earnings for the most recent 8 quarters scaled by total assets (where $t=$ year 2015 to 2017); $F D_{(t-1)}$ is the usage of derivatives lagged by one year, measured as a dummy variable, 1 denotes users of derivatives and 0 otherwise; AudFS is the auditor firm size, measured as a dummy variable, 1 denotes a big-four firm and 0 otherwise; $G r$ is the growth opportunity, measured as market value of the ordinary (common) equity divided by book value of the ordinary (common) equity; FS is the firm size, measured by natural logarithm of total assets; Lev is the leverage, measured by percentage of total liabilities divided by total assets. Figures in parentheses are standard errors of the estimates.

derivatives. Most companies tend to justify usage of derivatives as a tool to reduce their risk of exposure and earnings volatility (El-Masry, 2006; Geczy et al., 1997; Jalilvand et al., 2000; Shen \& Hartarska, 2013) as proposed by corporate risk management theory. Based on the observations from the content analysis in the annual reports that revealed that most of the sample firms provided information pertaining to derivatives under the risk management disclosure section, this implies that derivative use is designated for risk management purposes. Therefore, the evidence of a positive relationship between derivative use and earnings volatility may suggest that derivative users among Malaysian firms are less effective in hedging their risks using financial derivatives. In addition, as pointed out by Nordin Zain, the Executive Director from Deloitte Malaysia, most CFOs and accountants have a shortage of knowledge in determining the need 
to use derivative instruments in their firms (Deloitte, 2009). This is also supported by Chang et al. (2016) who noted that financial analysts often fail to correctly evaluate the earnings implications of firms' derivative activities. However, the findings were not able to rule out the possibility that these firms may engage in derivatives with the intent to speculate and end up exposing themselves to higher earnings volatility. This is because this study was not able to segregate derivative users with the intent to hedge and speculate due to the limitation of the measurement used to identify derivative users.

Model 2 examined the association between earnings volatility and earnings management and answered hypothesis 2 . The findings revealed that earnings volatility is positively related to earnings management, with a coefficient of 0.0045 at $1 \%$ significance level. This indicates that when a firm's earnings become more volatile, the level of earnings management will increase accordingly. In other words, this provides support to the view that firms were motivated to engage in earnings management to mitigate earnings volatility.

Model 3 investigated the relationships between usage of derivatives and earnings management. The result shows a positive relationship between usage of derivatives and earnings management with a coefficient of 0.0249 at $5 \%$ significance level. As the present study attempts to measure derivatives using lag year, the findings support Pincus and Rajgopal (2002) who are of the opinion that usage of derivatives and earnings management is a sequential process. Inefficient use of derivatives appears to be a factor that has driven firms to engage in earnings management.

Model 4 is an expansion of the Model 3 that includes derivative use $\left(F_{t-1}\right)$ and earnings volatility (EV) simultaneously into the regression model so that the impact of derivative use on earnings management can be studied when the effect of earnings volatility is controlled. The results are consistent with Model 3, where the usage of derivatives affects earnings management positively with a coefficient of 0.0221 at $5 \%$ significance level.

\subsection{Robustness Test}

For the robustness test, the researchers repeated the panel data processing with a least squares dummy variable (LSDV) regression (OLS with a set of year-dummies) to notice year effect more distinctively. If fixed effects are present during a period of three-year observations, a static panel data model can be estimated using the LSDV estimator (Zhou \& Wang, 2018). Table 5 shows the results with year-fixed-effects. The results are highly similar with Table 4 . None of the significant coefficients changed signs.

Again, Model 5 showed a significant and positive relationship between the usage of derivatives and earnings volatility, which implies that firms with usage of derivatives are more volatile in their financial performance. The results of Model 6 confirmed earlier findings that earnings volatility has a positive impact on earnings management. Similarly, Model 7 reported that usage of derivatives affects earnings management positively. Lastly, the results of Model 8 also showed a positive impact of usage of derivatives on earnings management when earnings volatility was controlled. Therefore, all the results were consistent with either fixed effect estimation with least squares dummy variable or pooled OLS estimation. 
Table 5. Fixed-effects estimation

\begin{tabular}{|c|c|c|c|c|}
\hline & Model 5 & Model 6 & Model 7 & Model 8 \\
\hline Dependent variable & EV & EM & EM & EM \\
\hline $\mathrm{FD}_{(t-1)}$ & $\begin{array}{c}\mathbf{0 . 6 5 1 2 *} \\
(0.3507)\end{array}$ & & $\begin{array}{l}0.0244^{* *} \\
(0.0098)\end{array}$ & $\begin{array}{l}\mathbf{0 . 0 2 1 7}^{* *} \\
(0.0098)\end{array}$ \\
\hline EV & & $\begin{array}{l}0.0047^{* * *} \\
(0.0014)\end{array}$ & & $\begin{array}{l}\mathbf{0 . 0 0 4 3}^{* * *} \\
(0.0015)\end{array}$ \\
\hline AudFS & $\begin{array}{c}0.2530 \\
(0.4095)\end{array}$ & 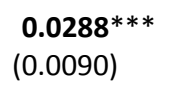 & $\begin{array}{l}\mathbf{0 . 0 3 0 2} * * * \\
(0.0115)\end{array}$ & $\begin{array}{l}\text { 0.0291** } \\
(0.0113)\end{array}$ \\
\hline $\mathrm{Gr}$ & $\begin{array}{l}-0.0455^{*} \\
(0.0254)\end{array}$ & $\begin{array}{c}0.0000 \\
(0.0005)\end{array}$ & $\begin{array}{l}-0.0003 \\
(0.0007)\end{array}$ & $\begin{array}{l}-0.0001 \\
(0.0007)\end{array}$ \\
\hline FS & $\begin{array}{l}-0.6860 * \\
(0.3681)\end{array}$ & $\begin{array}{l}-0.0317^{* * *} \\
(0.0077)\end{array}$ & $\begin{array}{l}-0.0454 * * * \\
(0.0103)\end{array}$ & $\begin{array}{l}-0.0425 * * * \\
(0.0102)\end{array}$ \\
\hline Lev & $\begin{array}{c}0.0112 \\
(0.0096)\end{array}$ & $\begin{array}{c}0.0002 \\
(0.0002)\end{array}$ & $\begin{array}{c}0.0004 \\
(0.0003)\end{array}$ & $\begin{array}{c}0.0004 \\
(0.0003)\end{array}$ \\
\hline _cons & $\begin{array}{l}7.2458^{* *} \\
(3.4358)\end{array}$ & $\begin{array}{l}0.3438^{* * *} \\
(0.0727)\end{array}$ & $\begin{array}{l}0.4390^{* * *} \\
(0.0961)\end{array}$ & $\begin{array}{l}\mathbf{0 . 4 0 8 2 * * *} \\
(0.0958)\end{array}$ \\
\hline $\mathrm{N}$ & 338 & 507 & 338 & 338 \\
\hline$r^{2}$ & 0.0258 & 0.0891 & 0.0843 & 0.1055 \\
\hline
\end{tabular}

Note: $* * *, * * *$ denotes significance level at $10 \%, 5 \%$ and $1 \%$ respectively.

EM is the discretionary accrual, Total Accrual/ $A_{t-1}=\alpha_{1}\left(1 / A_{t-1}\right)+\alpha_{2}\left(\Delta R E V_{i t}-\Delta R E C_{i t}\right) / A_{t-1}+\alpha_{3}\left(P P E_{i t} / A_{t-1}\right)+$ $\varepsilon$ (Modified Jones model); $E V$ is the earnings volatility, measured as the standard deviation of earnings for the most recent 8 quarters scaled by total assets (where $t=$ year 2015 to 2017); $F D_{(t-1)}$ is the usage of derivatives lagged by one year, measured as a dummy variable, 1 denotes users of derivatives and 0 otherwise ; AudFS is the auditor firm size, measured as a dummy variable, 1 denotes a big-four firm and 0 otherwise; $\mathrm{Gr}$ is the growth opportunity, measured as market value of the ordinary (common) equity divided by book value of the ordinary (common) equity; FS is the firm size, measured by natural logarithm of total assets; Lev is the leverage, measured by percentage of total liabilities divided by total assets. Figures in parentheses are standard errors of the estimates.

\subsection{Endogeneity}

The researchers used two-stage least-squares regressions to mitigate endogeneity concerns. In the first stage, earnings volatility was modelled. It was expected that fluctuations in operating cash flows affect earnings volatility (EV) but not earnings management (EM). Therefore, the instrumental variables include: (1) SDEVOCF, calculated by the standard deviation of operating cash flows for the previous eight quarters divided by the standard deviation of EBIT, (2) factor variable for the industry that are correlated with EV but not the error term. Table 6 presents the results of the two-stage least-squares regressions. The SDEVOCF was negatively associated with earnings volatility. Although not reported, SDEVOCF was not significant when regressed on earnings management (EM), thus SDEVOCF is a candidate for the instrumental variable. Predicted earnings volatility (EV) was estimated in the first stage on the 
Table 6. Two stage least squares regressions

\begin{tabular}{lcc}
\hline & \multicolumn{1}{c}{ First stage } & Second stage \\
\cline { 2 - 3 } Dependent variable & EV & EM \\
\hline SDEVOCF & $-\mathbf{0 . 3 6 4 1 ^ { * }}$ & \\
Predicted EV & $(0.2135)$ & \\
& & $\mathbf{0 . 0 1 4 8 * *}$ \\
AudFS & 0.0673 & $(0.0067)$ \\
& $(0.2932)$ & $\mathbf{0 . 0 2 4 2 * *}$ \\
Gr & -0.0224 & $(0.0095)$ \\
& $(0.0179)$ & 0.0003 \\
Lev & 0.0106 & $(0.0006)$ \\
& $(0.0068)$ & -0.0000 \\
ccons & $\mathbf{0 . 7 1 5 7 ^ { * }}$ & $(0.0002)$ \\
& $(0.3673)$ & $\mathbf{0 . 0 4 1 1 * * *}$ \\
$\mathrm{N}$ & 507 & $(0.0128)$ \\
\hline
\end{tabular}

Note: The first-stage regression models earnings volatility (EV) is the standard deviation of earnings for the most recent 8 quarters scaled by total assets. It includes two instrumental variables: (i) SDEVOCF, calculated by the standard deviation of operating cash flows for the previous eight quarters divided by the standard deviation of EBIT, and (ii) factor variable for the industry. The dependent variable in the second-stage regression is the earnings management (EM). Predicted EV is the predicted earnings volatility from the first stage regression. AudFS is the auditor firm size, measured as a dummy variable, 1 denotes a big-four firm and 0 otherwise; $\mathrm{Gr}$ is the growth opportunity, measured as market value of the ordinary (common) equity divided by book value of the ordinary (common) equity; Lev is the leverage, measured by percentage of total liabilities divided by total assets. All models include dummy variables for year effects (not tabulated). $* * *, * *$, and $*$ denote statistical significance at the $1 \%, 5 \%$ and $10 \%$ levels, respectively. Figures in parentheses are standard errors of the estimates.

earnings management (EM). After controlling for endogeneity, the researchers found that earnings volatility (EV) affects earnings management (EM) positively. Moreover, the results were also consistent for the control variable that audit firm size has a positive impact on earnings management.

\section{Conclusion}

This study documented a positive relationship between derivative use and earnings volatility (Model 1). Interestingly, the findings do not provide evidence to support corporate risk management theory, which anticipated that derivative instruments were designed for an organisation's financial stability to protect firms from adverse market price fluctuations in the underlying market. This seems contradictory to the motive for 
derivative use, as the details pertaining to derivatives are presented as components of risk management disclosure in their annual reports by the sample firms.

The evidence derived from Models 2, 3 and 4 that examined the relationship between earnings volatility and earnings management as well as between derivative use and earnings management suggested that earnings volatility would trigger firms to engage in earnings management, whereas the use of derivatives increases earnings management. The results imply that firms that failed to reduce earnings volatility with the use of derivatives would exercise managerial discretion by manipulating accounting accruals as the means to smooth earnings. As the data indicate that most of the firms engage with derivatives to manage foreign currency related risks, derivative use is shown to be a risk management tool. However, the outcomes of hedging are not favourable to a large extent. Given that derivative use is complicated, this calls for further investigation to determine whether the findings were attributable to inefficient use of derivatives or the speculative behaviour of managers. The findings provide new evidence from an emerging market to extend the literature on derivative use, earnings volatilit, and earnings management as the contextual environment is different from those of developed countries.

Apart from that, this study is timely and provides empirical evidence that the use of financial derivatives affects earnings volatility and influences earnings management practices. This study provides evidence to the strand of research that suggested the sequential process whereby managers first make hedging decisions and then, at the margin, use discretionary accrual based on the pioneer work of Pincus and Rajgopal (2002).

From the perspectives of practitioners, this study may aid investors, financial analysts, boards of directors, professional bodies, regulators, firms and other related parties in reasonably evaluating how the use of derivatives affects earnings volatility and in assessing how earnings volatility will influence earnings management practices.

There were several limitations encountered throughout the study. First, the findings have to be considered with caution because the sample for this study was selected only from the top 200 listed companies. Due to this sample selection decision, the findings can only be generalised for large companies in Malaysia. The effect of the magnitude of derivatives usage was not examined in this study due to data constraints. Prior research in the developed countries had used total or aggregate notional values as a measure of derivatives (Barton, 2001; Pincus \& Rajgopal, 2002; Singh, 2004). More specifically, derivatives are defined as the aggregate total notional value of all reported derivative contracts held for non-trading purposes outstanding at the end of the fiscal year for each firm and scaled by the market value of assets at the end of the fiscal year. However, there is no standard measurement for derivative usage in Malaysia, as some of the firms that are using derivatives did not disclose the total notional value of all reported derivatives in their annual reports. Therefore, this measurement was not applicable in this study.

Future research could involve all listed companies in the main board of Bursa Malaysia in order to increase the sample size of the study and to generalise the results to companies of smaller sizes as well. In addition, longer longitudinal data could be studied to have a better understanding on how derivatives are used as a strategic risk 
management tool. In the context of Malaysia, this study showed that when Malaysian listed companies engaged in the use of financial derivatives, earnings management activities also increased. There needs to be more research to enhance understanding about the interacting effect of the use of derivatives on earnings management and earnings volatility by drawing on larger sample sets using cross countries data from developing countries.

With the implementation of new accounting standards for financial instruments effective from 1 January 2019, future research may also look into the effect of accounting regulations on derivative use (Choi et al., 2015), as findings from developed countries show that for firms that aim at reducing earnings volatility, hedge accounting would encourage them to use derivatives for hedging purposes (Abdel-khalik \& Chen, 2015).

\section{References}

Abdel-khalik, A.R., \& Chen, P-C. (2015). Growth in financial derivatives: The public policy and accounting incentives. Journal of Accounting and Public Policy, 34(3), 291-318. https://doi. org/10.1016/j.jaccpubpol.2015.01.002

Abdullah, S.N., \& Ismail, K.N.I.K. (2016). Women directors, family ownership and earnings management in Malaysia. Asian Review of Accounting, 24(4), 525-550. https://doi. org/10.1108/ARA-07-2015-0067

Alkebäck, P., Hagelin, N., \& Pramborg, B. (2006). Derivative usage by non-financial firms in Sweden 1996 and 2003: What has changed? Managerial Finance, 32(2), 101-114. https://doi. org/10.1108/0307435061064189

Assa, H. (2016). Financial engineering in pricing agricultural derivatives based on demand and volatility. Agricultural Finance Review, 76(1), 42-53.

Barnes, R. (2002). Accounting for derivatives and corporate risk management policies. SSRN Electronic Journal. https://doi.org/10.2139/ssrn.298021

Barton, J. (2001). Does the use of financial derivatives affect earnings management decisions? The Accounting Review, 76(1), 1-26.

Beneda, N. (2013). The impact of hedging with derivative instruments on reported earnings volatility. Applied Financial Economics, 23(2), 165-179. https://doi.org/10.1080/09603107. 2012.709599

Brown, G.W. (2000). Managing foreign exchange risk. Journal of Financial Economics, 60(2-3), 401448. https://doi.org/10.1016/S0304-405X(01)00049-6

Campbell, J.L., Mauler, L.M., \& Pierce, S.R. (2019). A review of derivatives research in accounting and suggestions for future work. Journal of Accounting Literature, 42(June), 44-60. https:// doi.org/10.1016/j.acclit.2019.02.001

Chang, H.S., Donohoe, M., \& Sougiannis, T. (2016). Do analysts understand the economic and reporting complexities of derivatives? Journal of Accounting and Economics, 61(2-3), 584604. https://doi.org/10.1016/j.jacceco.2015.07.005

Choi, J.J., Mao, C.X., \& Upadhyay, A.D. (2015). Earnings management and derivative hedging with fair valuation: Evidence from the effects of FAS 133. The Accounting Review, 90(4), 14371467. https://doi.org/10.2308/accr-50972

Cohen, D.A., \& Zarowin, P. (2010). Accrual-based and real earnings management activities around seasoned equity offerings. Journal of Accounting and Economics, 50(1), 2-19. https://doi. org/10.1016/j.jacceco.2010.01.002

Cox, J. (2018, May 4). The value of what Buffett called 'financial weapons of mass destruction' is plunging. CNBC. https://www.cnbc.com/2018/05/04/the-value-of-financial-weapons- 
of-mass-destruction-is-plunging.html\#: :text=\%E2\%80\%9CIn\%20my\%20view\%2C\%20 derivatives\%20are,latent\%2C\%20are\%20potentially\%20lethal.\%E2\%80\%9D

DeAngelo, L.E. (1986). Accounting numbers as market valuation substitutes: A study of management buyouts of public stockholders. The Accounting Review, 61(3), 400-420.

Dechow, P., Ge, W., \& Schrand, C. (2010). Understanding earnings quality: A review of the proxies, their determinants and their consequences. Journal of Accounting and Economics, 50(2-3), 344-401. https://doi.org/10.1016/j.jacceco.2010.09.001

Dechow, P.M., \& Sloan, R.G. (1991). Executive incentives and the horizon problem: An empirical investigation. Journal of Accounting and Economics, 14(1), 51-89. https://doi. org/10.1016/0167-7187(91)90058-S

Dechow, P.M., Sloan, R.G., \& Sweeney, A.P. (1995). Detecting earnings management. The Accounting Review, 70(2), 193-225.

Deloitte. (2009). Looking forward, sharing insights. Point of View, 2(December), 1-15.

Dichev, I.D., \& Tang, V.W. (2008). Matching and the changing properties of accounting earnings over the last 40 years. The Accounting Review, 83(6), 1425-1460. https://doi.org/10.2308/ accr.2008.83.6.1425

El-Masry, A.A. (2006). Derivatives use and risk management practices by UK nonfinancial companies. Managerial Finance, 32(2), 137-159. https://doi.org/10.1108/03074350610 64191

Geczy, C., Minton, B.A., \& Schrand, C. (1997). Why firms use currency derivatives. The Jourrnal of Finance, 52(4), 1323-1354. https://doi.org/10.2307/2329438

Ghazali, A.W., Shafie, N.A., \& Sanusi, Z.M. (2015). Earnings management: An analysis of opportunistic behaviour, monitoring mechanism and financial distress. Procedia Economics and Finance, 28, 190-201. https://doi.org/10.1016/S2212-5671(15)01100-4

Glaum, M., \& André Klöcker, A. (2011). Hedge accounting and its influence on financial hedging: When the tail wags the dog. Accounting and Business Research, 41(5), 459-489. https://doi. org/10.1080/00014788.2011.573746

Goel, A.M., \& Thakor, A.V. (2003). Why do firms smooth earnings? The Journal of Business, 76(1), 151-192. https://doi.org/10.1086/344117

Hairston, S.A., \& Brooks, M.R. (2019). Advances in accounting derivative accounting and financial reporting quality: A review of the literature. Advances in Accounting, 44(March), 81-94. https://doi.org/10.1016/j.adiac.2018.10.003

Healy, P.M. (1985). The effect of bonus schemes on accounting decisions. Journal of Accounting and Economics, 7(1-3), 85-107. https://doi.org/10.1016/0165-4101(85)90029-1

Holthausen, R.W., Larcker, D.F., \& Sloan, R.G. (1995). Annual bonus schemes and the manipulation of earnings. Journal of Accounting and Economics, 19(1), 29-74. https://doi. org/10.1016/0165-4101(94)00376-G

Hon, T-Y. (2013). Managing financial risk by using derivatives: A study of Hong Kong listed companies. Elk Asia Pacific Journal of Finance \& Risk Management, 4(1), 1-16.

Hu, Z.H., \& Zhou, Y. (2006). Accounting for financial derivatives and its effects on earnings volatility (Master's Thesis, Simon Fraser University, Burnaby, BC, Canada). file:///C:/Users/ User/Downloads/etd2419.pdf

Huang, S.Y., Chung, Y-H, Chiu, A-A., \& Chen, Y-C. (2015). Growth opportunity and risk: Empirical investigation on earnings management decision. Investment Management and Financial Innovations, 12(2), 299-309.

IOI Corporation Berhad. (2015). IOI Group Annual Report 2015. https://www.ioigroup.com/ Content/IR/PDF/AR/2015_AR.pdf

Jacque, L.L. (2010). Global derivative debacles: From theory to malpractice. World Scientific Publishing Co. Pte. Ltd. 
Jalilvand, A., Jeannette Switzer, J., \& Tang, C. (2000). A global perspective on the use of derivatives for corporate risk management decisions. Managerial Finance, 26(3), 29-38. https://doi. org/10.1108/03074350010766567

Jones, J.J. (1991). Earnings management during import relief investigations. Journal of Accounting Research, 29(2), 193-228. https://doi.org/10.2307/2491047

Jordan, C.E., Clark, S.J., \& Hames, C.C. (2010). The impact of audit quality on earnings management to achieve user reference points in EPS. Journal of Applied Business Research, 26(1), 19-30. https://doi.org/10.19030/jabr.v26i1.273

Kousenidis, D., Negakis, C., \& Papanastasiou, I. (2003). The value relevance of earnings and income smoothing: Greek evidence on causality effects. European Research Studies, 6(3-4), 85-94.

Lau, C.K. (2016). How corporate derivatives use impact firm performance? Pacific-Basin Finance Journal, 4O(Part A), 102-114. https://doi.org/10.1016/j.pacfin.2016.10.001

Lin, C-H. (2011). Exchange rate exposure in the Asian emerging markets. Journal of Multinational Financial Management, 21(4), 224-238. https://doi.org/10.1016/j.mulfin.2011.04.002

Manning, J. (2015). Accounting for the Malaysian Ringgit's slump in 2015. International Banker. Retrieved August 1, 2020, from https://internationalbanker.com/brokerage/accounting-forthe-malaysian-ringgits-slump-in-2015/

Mohd Saleh, N., Mohd Iskandar, T., \& Mohid Rahmat, M. (2007). Audit committee characteristics and earnings management: Evidence from Malaysia. Asian Review of Accounting, 15(2), 147163. https://doi.org/10.1108/13217340710823369

Oktavia, O., Siregar, S.V., Wardhani, R., \& Rahayu, N. (2019). The effects of financial derivatives on earnings management and market mispricing. Gadjah Mada International Journal of Business, 21(3), 289-307. https://doi.org/10.22146/gamaijb.34112

Oppel, Jr., R.A., \& Sorkin, A.R. (2001, November 29). Enron's collapse: The overview; Enron collapses as suitor cancels plans for merger. The New York Times. Retrieved September 9, 2020 from https://www.nytimes.com/2001/11/29/business/enron-s-collapse-the-overviewenron-collapses-as-suitor-cancels-plans-for-merger.html

Pincus, M., \& Rajgopal, S. (2002). The interaction between accrual management and hedging: Evidence from oil and gas firms. The Accounting Review, 77(1), 127-60. https://doi. org/10.2308/accr.2002.77.1.127

Quadry, M.O., Mohamad, A., \& Yusof, Y. (2017). On Malaysian Ringgit exchange rate determination and recent depreciation. International Journal of Economics, Management and Accounting, 25(1), 1-26.

Shen, X., \& Hartarska, V. (2013). Derivatives as risk management and performance of agricultural banks. Agricultural Finance Review, 73(2), 290-309. https://doi.org/10.1108/AFR-07-20120036

Singh, A. (2004). The effects of SFAS 133 on the corporate use of derivatives, volatility, and earnings management (Doctoral thesis, The Pennsylvania State University, Pennsylvania). https://etda.libraries.psu.edu/catalog/6437

Smith, C.W., \& Stulz, R.M. (1985). The determinants of firms' hedging policies. The Journal of Financial and Quantitative Analysis, 20(4), 391-405. https://doi.org/10.2307/2330757

Tahat, Y., Dunne, T., Fifield, S., \& Power, D. (2019). Risk-related disclosure: A review of the literature and an agenda for future research. Accounting Forum, 43(2), 193-219. https://doi. org/10.1080/01559982.2019.1584953

Tort, L.P. (2013). Earnings management under IFRS and PGC. Revista de Contabilidade y Direccion, 16(1), 161-185.

Wan Mohammad, W.M., Wasiuzzaman, S., \& Nik Salleh, N.M.Z. (2016). Board and audit committee effectiveness, ethnic diversification and earnings management: A study of the Malaysian 
manufacturing sector. Corporate Governance, 16(4), 726-746. https://doi.org/10.1108/CG06-2015-0085

Verdickt, G., Annaert, J., \& Deloof, M. (2019). Dividend growth and return predictability: A longrun re-examination of conventional wisdom. Journal of Empirical Finance, 52, 112-127. https://doi.org/10.1016/j.jempfin.2019.03.002

Zhou, C., \& Wang, S. (2018). Examining the determinants and the spatial nexus of city-level CO2 emissions in China: A dynamic spatial panel analysis of China's cities. Journal of Cleaner Production 171, 917-926. https://doi.org/10.1016/j.jclepro.2017.10.096 